\title{
OPEN Correlation of P-wave velocity with mechanical and physical properties of limestone with statistical analysis
}

\begin{abstract}
Hasan Arman (1D)
This study aims to investigate the correlation between the $P$-wave velocity $\left(V_{p}\right)$ and the mechanical and the physical properties of the limestone; $V_{p}$ tests were conducted on over 320 limestone samples. Moreover, the effects of the mineralogical, textural, and chemical composition of limestone were also studied through thin sections, scanning electron microscopy (SEM), X-ray diffraction (XRD), and X-ray fluorescence (XRF). The relationships between the $V_{p}$ and the uniaxial compressive strength (UCS), point load index $\left(\mathrm{PLI}\left(\mathrm{I}_{s(50)}\right)\right.$, 2nd cycle of slake durability index $\left(\mathrm{I}_{\mathrm{d} 2}\right)$, natural unit weight $\left(\gamma_{n}\right)$, specific gravity $\left(G_{s(c)}\right)$, water absorption by weight (WA), and porosity $(n)$ were estimated using representative empirical equations. The empirical equations were validated by Student's $t$ test that has indicated the existence of strong relationships between the mechanical and physical properties of the intact limestone with $\mathrm{V}_{\mathrm{p}}$ i the calculated $\mathrm{t}$-values were higher than the $\mathrm{t}$-critical value. Furthermore, the results of previously available studies were compared with the results of this study in terms of the generated equations for $V_{p}$ values and the slope of a 1:1 line, which was used to appraise the predicted and measured values. This study demonstrates that the UCS, $\operatorname{PLI}\left(I_{s(50)}\right), I_{d 2}, Y_{n}, G_{s(c)}, W A$, and $n$ values of an intact limestone can be predicted by using $\mathrm{V}_{\mathrm{p}}$, which is fast, easy, economical and nondestructive test.
\end{abstract}

Seismic techniques are well understood, nondestructive, and low-cost methods that can be easily performed in the laboratory and in-situ. These techniques are widely used in civil, geological, mining, and rock engineering applications to characterize the dynamic properties of rocks. The seismic properties of rocks are influenced by numerous factors, such as the rock type, texture, mineralogical composition, grain shape and size, density, porewater, porosity, and water content ${ }^{1-6}$.

Characterization of rock materials in the field or laboratory requires the measurement of the mechanical and physical properties of rocks, which are critical tasks in many geotechnical and rock engineering projects. Moreover, such experimental studies are extremely expensive, tedious, and time consuming. Reliable modeling of empirical relationships among the mechanical and physical properties of rock materials can eliminate the need for such an expensive and tedious work and facilitate the estimation of the necessary critical design parameters.

Numerous researchers have already derived possible relationships between P-wave velocity $\left(\mathrm{V}_{\mathrm{p}}\right)$ and the mechanical and physical features of limestone using statistical methods like regression analyses (Table 1). Tugrul and Zarif ${ }^{1}$ examined the relationships between total porosity $\left(\mathrm{n}_{\mathrm{t}}\right)$, uniaxial compressive strength (UCS), and $\mathrm{V}_{\mathrm{p}}$ using linear empirical equations and found strong negative and positive relationships among the correlated parameters. Using simple linear relations, Yasar and Erdogan ${ }^{2}$ reported strong relationships among UCS, modulus of elasticity (E), density $(\rho)$, and $V_{p}$. Kahraman and Yeken ${ }^{3}$ conducted various tests, for instance, absorption of water by weight (WA), $\rho$, porosity ( $\mathrm{n}$ ), and $\mathrm{V}_{\mathrm{p}}$, on 14 different carbonate rocks and reported strong negative and positive correlations between $V_{p}$ and all studied physical parameters. Yagiz ${ }^{4}$ investigated the relationship between slake durability and some carbonate rock features, observing strong relationships between the 4th cycle of the slake durability index $\left(\mathrm{I}_{\mathrm{d} 4}\right)$ and $\mathrm{V}_{\mathrm{p}}$. Yagiz ${ }^{7}$ assessed the geotechnical properties of carbonate rocks using $\mathrm{V}_{\mathrm{p}}$ tests and found high to low positive and negative correlation coefficients in the relationships among UCS, E, effective porosity $\left(n^{\prime}\right)$, WA, Schmidt rebound value $(S H V)$, 2nd cycle of the slake durability index $\left(I_{d 2}\right)$, dry density $\left(\rho_{d}\right)$, saturated density $\left(\rho_{\mathrm{s}}\right)$, and $\mathrm{V}_{\mathrm{p}}$ using statistical analyses, including Student's $t$ test. Arman et al. ${ }^{5}$ reported moderate correlations among indirect tensile strength (ITS), point load index (PLI), and $\mathrm{V}_{\mathrm{p}}$. Using 45 limestone core 


\begin{tabular}{|c|c|c|c|}
\hline Researchers & Equations & $\mathbf{R}$ & Rock type \\
\hline \multirow{2}{*}{ Tugrul and Zarif $2000^{1}$} & $n_{t}=-0.62 V_{p}+5.37$ & -0.78 & \multirow{2}{*}{ Limestone } \\
\hline & $U C S=16.73 V_{p}+21.25$ & 0.94 & \\
\hline \multirow{3}{*}{ Yasar and Erdogan $2004^{2}$} & $V_{p}=0.0317 U C S+2.0195$ & 0.89 & \multirow{3}{*}{ Carbonates } \\
\hline & $V_{p}=0.0937 E+1.7528$ & 0.93 & \\
\hline & $V_{p}=4.3183 \rho-7.5071$ & 0.90 & \\
\hline \multirow{3}{*}{ Kahraman and Yeken $2008^{3}$} & $W A=-2.248 V_{p}+13.76$ & -0.95 & \multirow{3}{*}{ Carbonates } \\
\hline & $\rho=0.213 V_{p}+1.256$ & 0.91 & \\
\hline & $n=-4.733 V_{p}+29.377$ & -0.94 & \\
\hline Yagiz $2011^{4}$ & $I_{d 4}=1.131 V_{p}-93.26$ & 0.73 & Carbonates \\
\hline \multirow{8}{*}{ Yagiz $2011^{7}$} & $E=20.1 V_{p}-53$ & 0.95 & \multirow{8}{*}{ Carbonates } \\
\hline & $U C S=49.4 V_{p}-167$ & 0.89 & \\
\hline & $n^{\prime}=-5.19 V_{p}+27.1$ & -0.86 & \\
\hline & $W A=-2.23 V_{p}+11.6$ & -0.85 & \\
\hline & $S H V=11.68 V_{p}-6.64$ & 0.80 & \\
\hline & $I_{d 2}=0.71 V_{p}+95.7$ & 0.69 & \\
\hline & $\rho_{d}=0.19 V_{p}+1.61$ & 0.58 & \\
\hline & $\rho_{s}=0.14 V_{p}+1.88$ & 0.46 & \\
\hline \multirow{2}{*}{ Arman et al. $2014^{5}$} & $\operatorname{PLI}\left(I_{s(50)}\right)=1.25 V_{p}-5.4035$ & 0.61 & \multirow{2}{*}{ Limestone } \\
\hline & $I T S=1.0051 V_{p}-3.0393$ & 0.57 & \\
\hline \multirow{2}{*}{ Najibi et al. $2015^{8}$} & $E=0.169 V_{p}^{3.324}$ & 0.95 & \multirow{2}{*}{ Limestone } \\
\hline & $U C S=3.67 V_{p}^{2.14}$ & 0.90 & \\
\hline Stan-Kieczek $2016^{9}$ & $E=74 \operatorname{Ln}\left(V_{p}\right)-572$ & 0.86 & Carbonates \\
\hline \multirow{4}{*}{ Pappalardo et al. $2016^{10}$} & $U C S=0.443 e^{(1.091 V p)}$ & 0.92 & \multirow{4}{*}{ Limestone } \\
\hline & $U C S=10.57 V_{p}-19.9$ & 0.86 & \\
\hline & $E=2.784 V_{p}-5.434$ & 0.85 & \\
\hline & $n=0.9966 e^{(-0.333 V p)}$ & -0.97 & \\
\hline \multirow{3}{*}{ Jamshidi et al. $2016^{11}$} & $U C S=101.1 \ln \left(V_{p}\right)-802.8$ & 0.97 & \multirow{3}{*}{ Travertine } \\
\hline & $I T S=8.44 \ln \left(V_{p}\right)-66.2$ & 0.96 & \\
\hline & $P L I=6.67 \ln \left(V_{p}\right)-51.9$ & 0.96 & \\
\hline Jamshidi et al. $2017^{12}$ & $U C S=131.77 \ln \left(V_{p}\right)-1048$ & 0.91 & Limestone \\
\hline Ferreidooni and Khajevad $2018^{13}$ & $I_{d 2}=0.0004 V_{p}+96.34$ & 0.88 & Travertine \\
\hline Ali et al. $2018^{14}$ & $U C S=0.045 V_{p}+24.348$ & 0.81 & Limestone \\
\hline \multirow{2}{*}{ Kurtulus et al. $2018^{15}$} & $V_{p}=166.5 S H V-2698.1$ & 0.87 & \multirow{2}{*}{ Limestone } \\
\hline & $V_{p}=268 S H V-10,292$ & 0.92 & \\
\hline \multirow{4}{*}{ Wen et al. $2019^{6}$} & $E=0.013 V_{p}-30.31$ & 0.91 & \multirow{4}{*}{ Limestone } \\
\hline & $U C S=0.034 V_{p}-86.36$ & 0.89 & \\
\hline & $\rho=4.545^{*} 10^{-5} V_{p}+2.54$ & 0.82 & \\
\hline & $v=0.52-91 /\left(30.33+\left(V_{p}\right)^{0.69}\right)$ & 0.98 & \\
\hline \multirow{7}{*}{ This study } & $U C S=20.395 V_{p}-25.968$ & 0.67 & \multirow{7}{*}{ Limestone } \\
\hline & $\operatorname{PLI}\left(I_{s(50)}\right)=0.8023 V_{p}^{0.9448}$ & 0.71 & \\
\hline & $I_{d 2}=3.6869 \ln \left(V_{p}\right)+92.343$ & 0.72 & \\
\hline & $\gamma_{n}=18.328 V_{p}^{0.1614}$ & 0.76 & \\
\hline & $G_{s(C)}=-0.342 \ln \left(V_{p}\right)+2.5333$ & -0.76 & \\
\hline & $W A=-7.692 \ln \left(V_{p}\right)-15.956$ & -0.87 & \\
\hline & $n=-18.47 \ln \left(V_{p}\right)+38.8$ & -0.86 & \\
\hline
\end{tabular}

Table 1. Data of the correlation between some mechanical and physical properties of either carbonate rocks or limestone from published literature and this study. E: Modulus of Elasticity (GPa), UCS: Uniaxial Compressive Strength (MPa), PLI $\left(I_{s(50)}\right)$ : Point Load Index value (for $50 \mathrm{~mm}$ in diameter size sample) (MPa), ITS: Indirect Tensile Strength (MPa), SHV: Schmidt Rebound Value $(\mathrm{N}), V_{p}: \mathrm{P}$ Wave Velocity $\left(\mathrm{km} / \mathrm{s}\right.$ or m/s), $\gamma_{n}=$ natural unit weight $\left(\mathrm{kN} / \mathrm{m}^{3}\right) . W A=$ Water Absorption $(\%), n, n_{t}, n^{\prime}=$ Porosity, Total, Effective Porosity $(\%), G_{s(C)}$ : Specific Gravity for core samples, $I_{d 2}, I_{d 4}$ : Slake Durability Index, 2nd cycle, 4 th cycle (I), $v=$ Poisson's ratio, $\rho$, $\rho_{d}, \rho_{s}=$ Density, Dry Density, Saturated Density $\left(\mathrm{g} / \mathrm{cm}^{3}\right)$ and $R$ : Regression Coefficient.

specimens, Najibi et al. ${ }^{8}$ revealed relatively powerful relationships between E and UCS with $\mathrm{V}_{\mathrm{p}}$. Stan-Kieczek studied the elastic properties of carbonate rocks via laboratory and in-situ tests and reported a strong relationship between $\mathrm{E}$ and $\mathrm{V}_{\mathrm{p}}$. Pappalardo et al. ${ }^{10}$ performed a detailed laboratory characterization of the limestones 


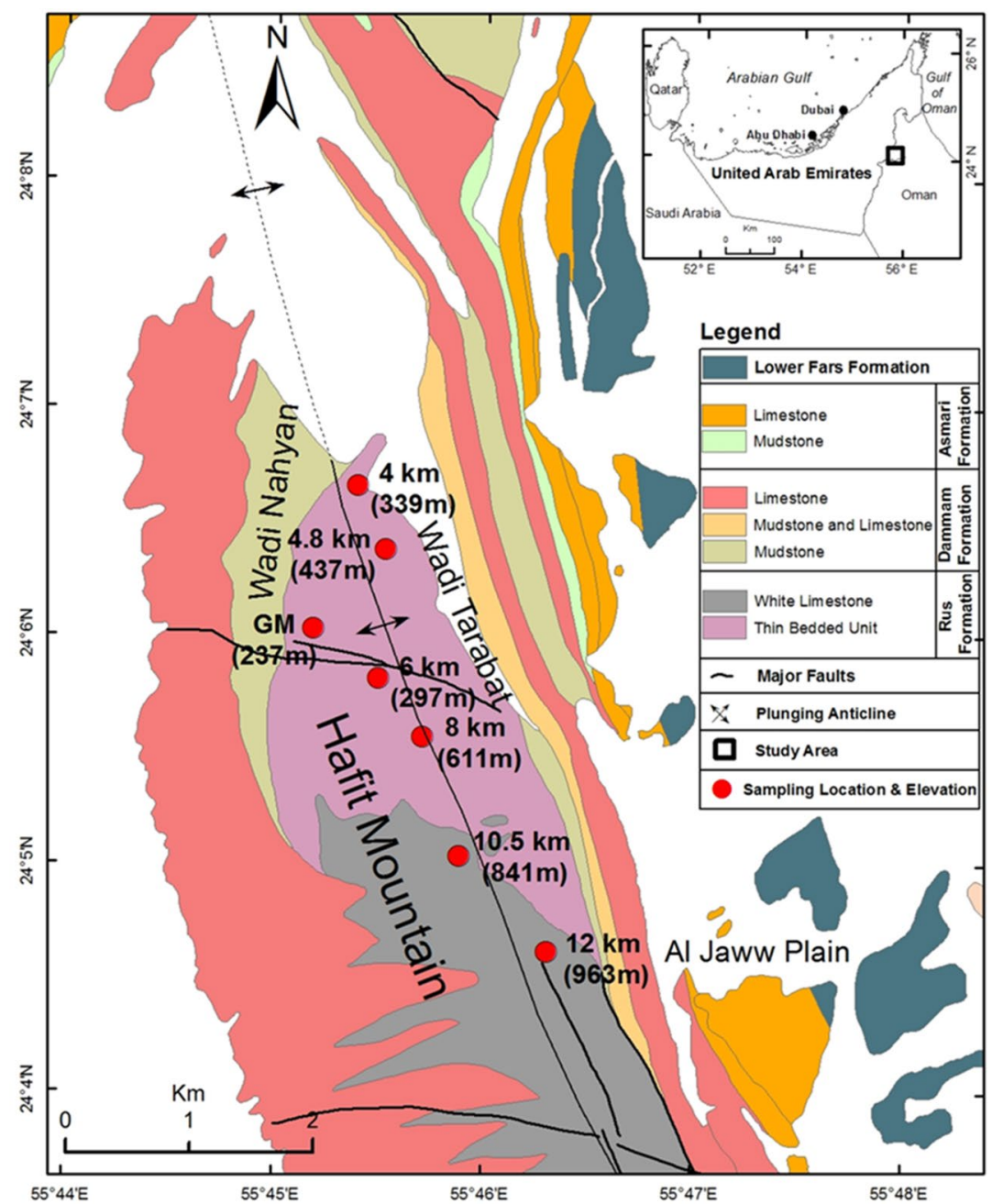

Figure 1. Location map of the sample sites with the geology of the Hafit Mountain (generated with ArcGIS $\left.10.8^{21}\right)$.

of heritage Baroque monuments and discovered strong positive and negative correlations between limestone $\mathrm{V}_{\mathrm{p}}$ and E, UCS, and n. Jamshidi et al. ${ }^{11}$ developed empirical equations to estimate the mechanical properties of travertine building stones from $V_{p}$ and Schmidt hardness. Jamshidi et al. ${ }^{12}$ examined the effects of $n$ and $\rho$ on the relationship between UCS and $V_{p}$ and noted a strong correlation between $V_{p}$ and UCS. Ferriodooni and Khajevad $^{13}$ investigated the relationships between engineering properties, slake durability index (SDI) of some travertine samples under the wetting-drying cycle, and observed a strong relationship between $\mathrm{I}_{\mathrm{d} 2}$ and $\mathrm{V}_{\mathrm{p}}$. Using an indirect method of comparative evaluation to approximate the compressive strength of limestone, Ali et al. ${ }^{14}$ reported a strong correlation between $\mathrm{V}_{\mathrm{p}}$ and UCS. Kurtulus et al. ${ }^{15}$ estimated the UCS using SHV and $\mathrm{V}_{\mathrm{p}}$, which proved to be strongly correlated. Wen et al. ${ }^{6}$ examined the correlation between geomechanics parameters and UCS and $V_{p}$ on 40 dolomitic limestone specimens and reported significant correlations among the parameters of E, UCS, $\rho$, and Poisson's ratio $(v)$.

Herein, the relationship between the mechanical and physical properties of limestone and $V_{p}$ were investigated. Further, the result of carbonate rocks or limestone obtained in previous studies were compared with those obtained in this study in terms of UCS, PLI $\left(\mathrm{I}_{\mathrm{s}(50)}\right), \mathrm{I}_{\mathrm{d} 2}, \gamma_{\mathrm{n}}, \mathrm{G}_{\mathrm{s}(\mathrm{c})}$, WA, and $\mathrm{n}$. Moreover, the reliability of the empirical relationship was validated using Student's $t$ test and the predicted and measured cross-correlation values from $\mathrm{V}_{\mathrm{p}}$.

\section{Study area and geological settings}

The study area, located along the Hafit Mountain, has been geologically well documented by numerous previous studies $^{16-20}$ (Fig. 1). The carbonate rocks of the Hafit Mountain-an asymmetric and doubly plunging anticlinewere dissected using numerous sets of faults. Tertiary carbonate rocks provide unique outcrops for three core rock units in the study area.

In the Hafit Mountain, the oldest rock unit is the Early Eocene Rus Formation, aged 55-49 Myr. It is thick bedded, massive, and generally appears grayish white in color. At some levels, brownish color chert nodules are dominated with dolomite layers. The Middle to Late Eocene Dammam Formation, aged 49-34 Myr, overlies 


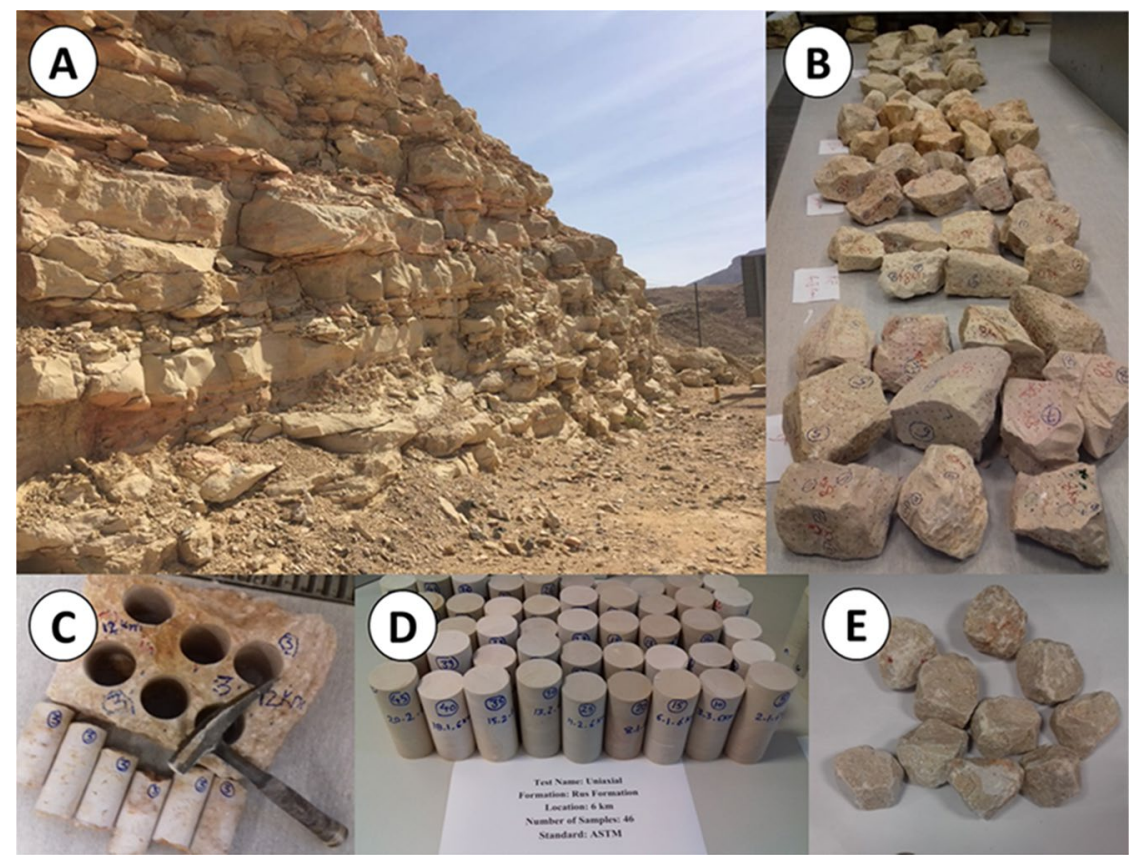

Figure 2. (A) General view of the Rus Formation and limestone outcrops, (B) a group of rock blocks collected from the field and used for coring and testing, (C) a cored rock block sample with core samples, (D) core samples prepared for the UCS test, and (E) test sample for the SDI test.

\begin{tabular}{|c|c|c|c|c|c|c|c|c|}
\hline $\begin{array}{l}\text { Sampling } \\
\text { location } \\
\text { (\# Total } \\
\text { samples) }\end{array}$ & \begin{tabular}{|l|}
$V_{p}$ \\
$(\mathbf{k m} / \mathbf{s})$ \\
$\mathbf{x} \pm \mathrm{SD}$ \\
(\# samples)
\end{tabular} & \begin{tabular}{|l|} 
UCS \\
(MPa) \\
$\mathbf{x} \pm$ SD \\
(\# samples)
\end{tabular} & $\begin{array}{l}\operatorname{PLI}\left(\mathrm{I}_{\mathrm{s}(50)}\right) \\
(\mathrm{MPa}) \\
\mathrm{x} \pm \mathrm{SD} \\
\text { (\# samples) }\end{array}$ & \begin{tabular}{|l}
$\mathrm{I}_{\mathrm{d} 2}$ \\
$(\%)$ \\
$\mathrm{X} \pm \mathrm{SD}$ \\
(\# samples)
\end{tabular} & $\begin{array}{l}\gamma_{\mathrm{n}} \\
\left(\mathbf{k N} / \mathbf{m}^{3}\right) \\
\mathrm{x} \pm \mathrm{SD} \\
\text { (\# samples) }\end{array}$ & $\begin{array}{l}\mathrm{G}_{\mathrm{s}(\mathrm{C})} \\
\mathrm{x} \pm \mathrm{SD} \\
\text { (\# samples) }\end{array}$ & \begin{tabular}{|l|} 
WA \\
$(\%)$ \\
$x \pm$ SD \\
(\# samples)
\end{tabular} & \begin{tabular}{|l|}
$\mathbf{n}$ \\
$(\%)$ \\
$\mathbf{x} \pm$ SD \\
(\# samples)
\end{tabular} \\
\hline $\begin{array}{l}\text { 1. }(0 \mathrm{~km}) \\
(212)\end{array}$ & $\begin{array}{l}6.04 \pm 0.94 \\
(36)\end{array}$ & $86 \pm 39(16)$ & $4 \pm 1.6(23)$ & $\begin{array}{l}98.35 \pm 0.53 \\
(13)\end{array}$ & $\begin{array}{l}23.85 \pm 1.10 \\
(62)\end{array}$ & $\begin{array}{l}1.96 \pm 0.09 \\
(36)\end{array}$ & $\begin{array}{l}2.69 \pm 1.44 \\
(13)\end{array}$ & $\begin{array}{l}6.67 \pm 3.52 \\
(13)\end{array}$ \\
\hline $\begin{array}{l}\text { 2. }(4 \mathrm{~km}) \\
(392)\end{array}$ & $4.93 \pm 1.1(71)$ & $84 \pm 38(36)$ & $4 \pm 1.3(37)$ & $\begin{array}{l}97.46 \pm 1.34 \\
(23)\end{array}$ & $\begin{array}{l}24.20 \pm 1.22 \\
(108)\end{array}$ & $\begin{array}{l}1.95 \pm 0.12 \\
(71)\end{array}$ & $\begin{array}{l}3.37 \pm 1.90 \\
(23)\end{array}$ & $\begin{array}{l}8.75 \pm 4.45 \\
(23)\end{array}$ \\
\hline $\begin{array}{l}\text { 3. }(4.8 \mathrm{~km}) \\
(102)\end{array}$ & $\begin{array}{l}5.38 \pm 0.88 \\
(18)\end{array}$ & $85 \pm 20(9)$ & $3 \pm 0.6(9)$ & $\begin{array}{l}97.97 \pm 0.80 \\
(7)\end{array}$ & $\begin{array}{l}23.44 \pm 0.89 \\
(27)\end{array}$ & $\begin{array}{l}2.01 \pm 0.08 \\
(18)\end{array}$ & $\begin{array}{l}3.59 \pm 1.23 \\
(7)\end{array}$ & $9.49 \pm 2.95(7)$ \\
\hline $\begin{array}{l}\text { 4. }(6 \mathrm{~km}) \\
(483)\end{array}$ & $\begin{array}{l}5.13 \pm 0.96 \\
(92)\end{array}$ & $83 \pm 41(46)$ & $4 \pm 1.3(46)$ & $\begin{array}{l}97.91 \pm 0.95 \\
(21)\end{array}$ & $\begin{array}{l}23.70 \pm 1.05 \\
(144)\end{array}$ & $\begin{array}{l}1.98 \pm 0.09 \\
(92)\end{array}$ & $\begin{array}{l}3.36 \pm 1.41 \\
(21)\end{array}$ & $\begin{array}{l}8.48 \pm 3.42 \\
(21)\end{array}$ \\
\hline $\begin{array}{l}5 .(8 \mathrm{~km}) \\
(227)\end{array}$ & $\begin{array}{l}4.85 \pm 1.74 \\
(43)\end{array}$ & $86 \pm 46(21)$ & $4 \pm 1.4(22)$ & $\begin{array}{l}95.78 \pm 5.04 \\
(11)\end{array}$ & $\begin{array}{l}23.53 \pm 1.96 \\
(65)\end{array}$ & $\begin{array}{l}2.03 \pm 0.19 \\
(43)\end{array}$ & $\begin{array}{l}4.95 \pm 4.28 \\
(11)\end{array}$ & $\begin{array}{l}12.37 \pm 10.52 \\
(11)\end{array}$ \\
\hline $\begin{array}{l}\text { 6. }(10.5 \mathrm{~km}) \\
(136)\end{array}$ & $\begin{array}{l}6.94 \pm 0.46 \\
(23)\end{array}$ & $110 \pm 31(12)$ & $9 \pm 0.5$ & $\begin{array}{l}98.30 \pm 0.35 \\
\text { (9) }\end{array}$ & $\begin{array}{l}25.04 \pm 0.58 \\
(40)\end{array}$ & $\begin{array}{l}1.90 \pm 0.06 \\
(23)\end{array}$ & $\begin{array}{l}1.27 \pm 0.71 \\
(9)\end{array}$ & $3.33 \pm 1.87(9)$ \\
\hline $\begin{array}{l}\text { 7. }(12 \mathrm{~km}) \\
(201)\end{array}$ & $\begin{array}{l}5.84 \pm 0.35 \\
(38)\end{array}$ & $68 \pm 26(19)$ & $5 \pm 0.9$ (19) & $\begin{array}{l}98.37 \pm 0.35 \\
(10)\end{array}$ & $\begin{array}{l}24.52 \pm 0.31 \\
(57)\end{array}$ & $\begin{array}{l}1.92 \pm 0.02 \\
(38)\end{array}$ & $\begin{array}{l}2.02 \pm 0.57 \\
(10)\end{array}$ & $\begin{array}{l}5.41 \pm 1.46 \\
(10)\end{array}$ \\
\hline
\end{tabular}

Table 2. Number of samples used for each test and the range within one standard deviation of the average. $x=$ average and $\mathrm{SD}=$ standard deviation.

the Rus Formation and exhibits some cavernous and fractured limestone layers, locally converting to chalky and dolomitic limestone with soft marl beds. Nummulitic limestone with marl beds is also available in different localized outcrops. The Early Oligocene Asmari Formation, aged 34-29 Myr, comprising mainly gypsiferous mudstone, nummulitic marly limestone, chalky and dolomitic limestone, and marl, is the youngest rock unit in the study $\operatorname{area}^{22}$.

The Early Miocene Lower Fars Formation, aged 23-16 Myr, comprises gypsite evaporates that are interbedded with friable marls and mudstones with gypsum veins, topped with a calcrete layer. The upper part comprises conglomeratic sandstone, rich in reworked chert and ophiolitic rock fragments ${ }^{23}$. The Miocene to Pliocene Barzaman Formation, aged 23-2 Myr, comprises a pebble-cobble conglomerate interbedded with sandstones and mudstones. The formation yields evidence for cycles of sedimentation from pluvial (wet) to arid, and the sediments of the arid intervals exhibit a white or pink color owing to dolomite alterations ${ }^{24}$. 


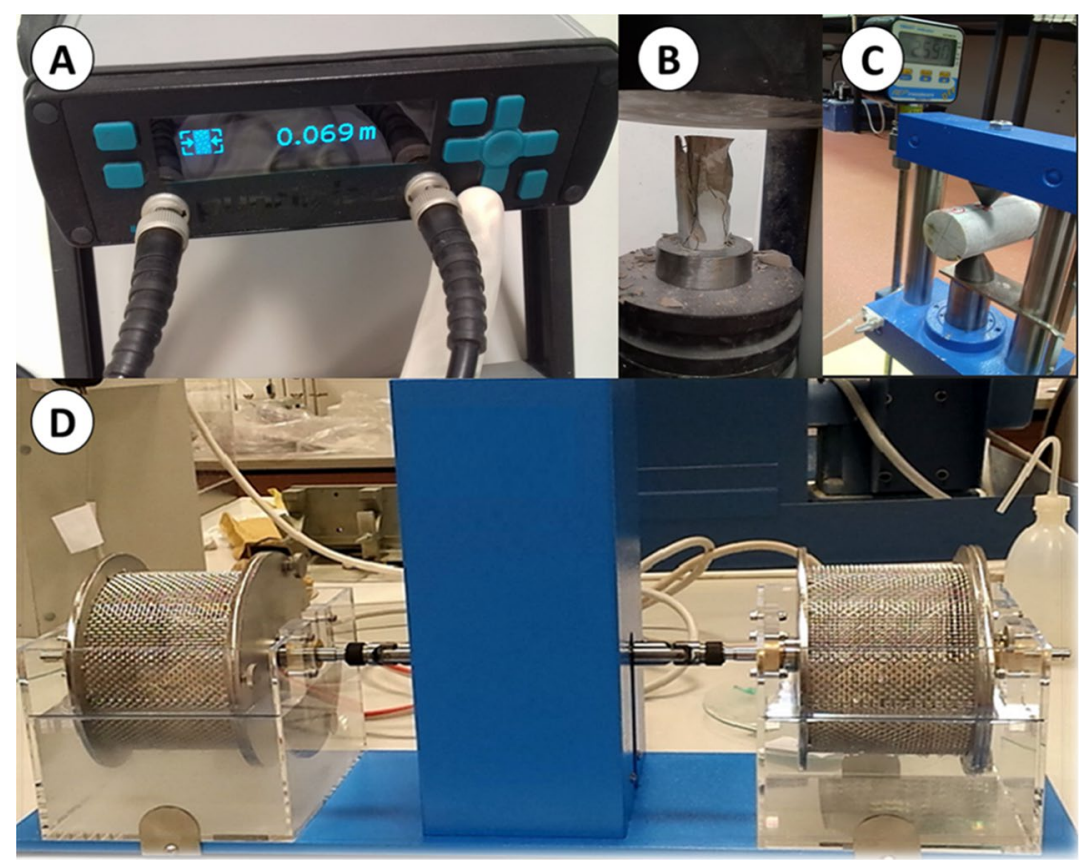

Figure 3. Laboratory equipment used for (A) $\mathrm{V}_{\mathrm{p}}$ measurements, Pundit Lab, (B) UCS test, servo plus evolution press (C) PLI test, and (D) SDI test.

\section{Rock sampling and laboratory studies}

Over 100 limestone rock blocks were collected along the seven selected sampling locations (Figs. 1 and 2A, B). Each rock block was carefully inspected for laboratory testing and analysis. The rock blocks were appropriately represented and provided standard testing specimens without visible defects, such as alteration zones and fractures. According to the American Society for Testing and Materials ${ }^{25}$ standards, core samples were acquired from 94 selected rock blocks for physical and mechanical tests (Fig. 2C-E]). Table 2 lists the number of samples used for each test (from seven sampling locations) with their average $(x)$ and standard deviation values. The tests were conducted on intact and natural rock samples. If the tests did not meet the suggested standards-owing to either core sample features or rock failing along the existing weakness plane-the results were not considered for examination.

With reference to the ASTM ${ }^{26}$ standards, for the $V_{\mathrm{p}}$ test, a portable pulse generator unit control, Pundit Lab, and two transducers with $25.4-\mathrm{mm}$ diameter and $250-\mathrm{kHz}$ frequency were used to measure the $\mathrm{V}_{\mathrm{p}}$ of the core samples (Fig. 3A). Further, $321 \mathrm{~V}_{\mathrm{p}}$ tests were conducted on limestone core specimens. According to Anon ${ }^{27}$ classifications, the $\mathrm{V}_{\mathrm{p}}$ of limestone indicates highly scattered ranges from 2.08 to 7.62 and can be classified as very low to very high.

The UCS, PLI, $I_{d 2}, \gamma_{n}, G_{s(c)}$, WA, and $n$ values of the limestone samples were determined following the ASTM and ISRM standards. Table 2 lists the descriptive statistical distribution of the test results. The UCS tests were conducted on $159 \mathrm{NX}$-sized core samples, which were prepared based on the ASTM ${ }^{28}$ standard, with approximately 2:1 length to diameter ratio. Further, smooth sample end surfaces were prepared, and a 0.5-1-MPa constant loading rate was axially applied to the core specimens (Fig. 3B). The PLI test was conducted on 167 regular $\mathrm{NX}$-sized core samples following the $\mathrm{ASTM}^{29}$ standard (Fig. 3C). If any sample failed either tests along existing cracks, weathered surfaces, or other weakness planes, the test results for such a sample was excluded. Moreover, 94 test samples were arranged for the SDI test from each rock block, and the SDI tests were conducted based on the $\mathrm{ASTM}^{30}$ standard (Fig. 3D). Based on a study by Franklin and Chandra ${ }^{31}, \mathrm{I}_{\mathrm{d} 2}$ was evaluated as a very high to extremely high SDI. The $\gamma_{\mathrm{n}}$ values of regular limestone core samples were calculated for approximately 500 test samples of UCS, PLI, and ITS test samples following the suggested method of the ISRM ${ }^{32}$. Based on the recommended methods of the ISRM ${ }^{32}, 321$ core samples were used to calculate the $G_{s(c)}$. Further, the WA and $n$ values were determined for each of the 94 limestone rock blocks using representative samples.

\section{Mineralogical and textural studies of rock units}

Mineralogical and textural evaluation was conducted on 27 selected carbonate rock samples covering the entire study area. The representative and detailed evaluation were performed on two selected carbonate rock samples, L2 and L11, discussed in here. As shown in Fig. 4 [L2-A1 and 2], clear dolomite rhombohedra crystals were found within a calcite matrix and cement, which can be described as dolostones. The X-ray diffraction (XRD) studies also show dolomite as the dominant mineral (Fig. 4 [L2-A3]). The chemical composition of the dolostones was approximately $0.8 \mathrm{wt} \% \mathrm{SiO}_{2}, 12 \mathrm{wt} \% \mathrm{MgO}, 41 \mathrm{wt} \% \mathrm{CaO}$, and $0.3 \mathrm{wt} \% \mathrm{Fe}_{2} \mathrm{O}_{3}$ (Table 3). The limestones, classified as fossiliferous limestone and dominated by calcite mineral, contained foraminifera, calcareous algae, and coral reef fragments. They were the most common materials in the study area (Fig. 4 [L11-B1, 2, and 3]). The chemical 

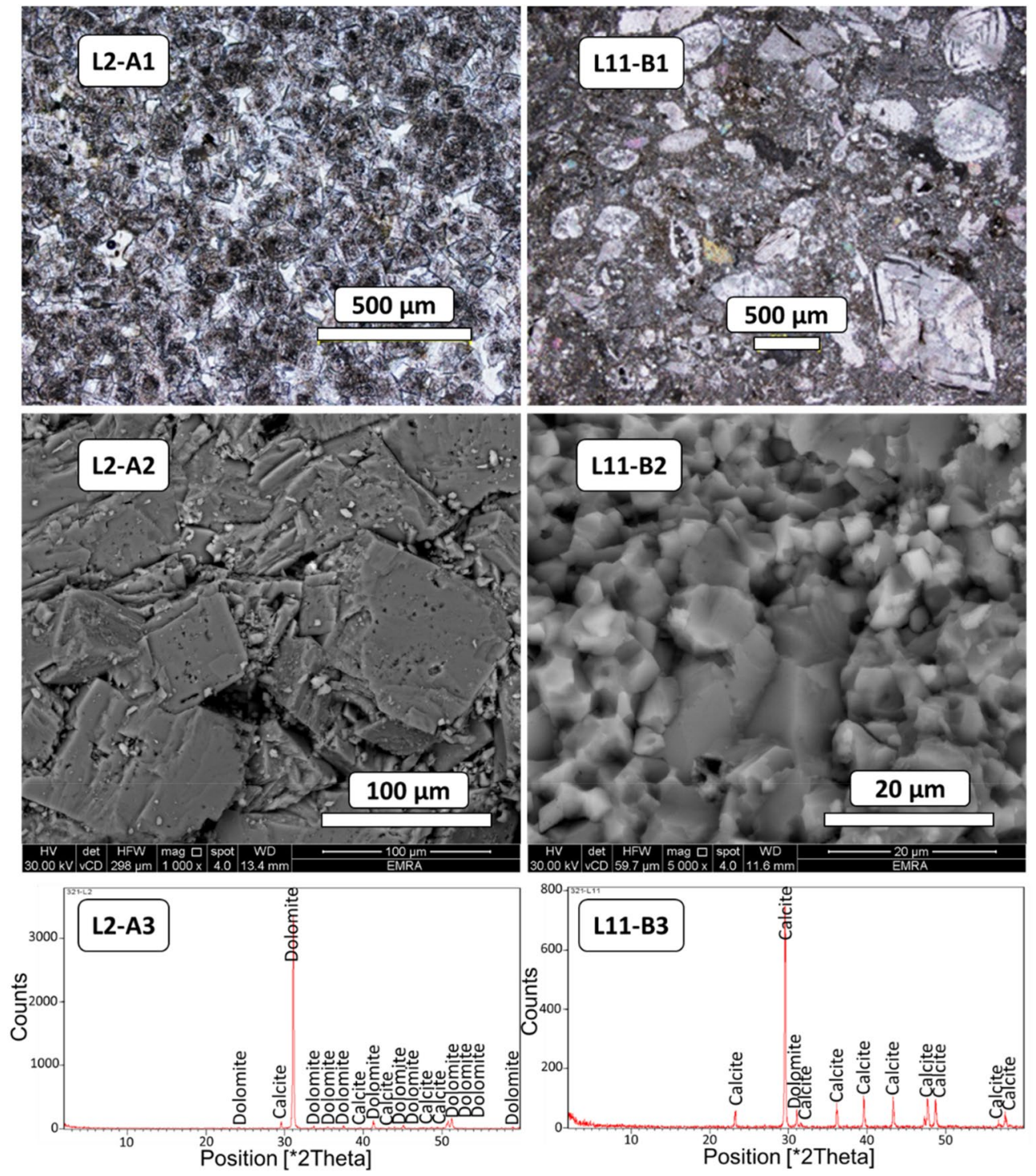

Figure 4. (L2-A1) Images of cross-polarized light showing relatively large dolomite crystals, (L2-A2) and (L2A3) showing texture and mineralogy of limestone: calcite matrix and cement enlarged using SEM in (L2-A2), minerals identified using XRD in (L2-A3). (L11-B1) Images of cross-polarized light showing relatively large fossils embedded in a dominantly calcite matrix (L11-B2) and (L11-B3) showing texture and mineralogy of limestone: calcite matrix enlarged using SEM in (L11-B2) and minerals identified using XRD in (L11-B3).

\begin{tabular}{|c|c|c|c|c|c|c|c|c|c|}
\hline \multirow[b]{2}{*}{ Samples } & \multicolumn{9}{|l|}{$w t \%$} \\
\hline & $\mathrm{SiO}_{2}$ & $\mathrm{Al}_{2} \mathrm{O}_{3}$ & $\mathrm{Fe}_{2} \mathrm{O}_{3}$ & $\mathrm{MnO}$ & MgO & $\mathrm{CaO}$ & $\mathrm{K}_{2} \mathrm{O}$ & $\mathrm{SO}_{3}$ & L.O.I \\
\hline L2 & 0.77 & 0.06 & 0.25 & 0.02 & 12.19 & 40.78 & 0.11 & $<0.01$ & 45.52 \\
\hline L11 & 0.5 & 0.07 & \begin{tabular}{|l|l|}
0.14 \\
\end{tabular} & 0.01 & $\begin{array}{l}0.22 \\
\end{array}$ & 55.3 & 0.03 & 0.01 & 43.35 \\
\hline
\end{tabular}

Table 3. Chemical analyses of the selected limestone.

composition of the fossiliferous limestone was approximately $0.5 \mathrm{wt} \% \mathrm{SiO}_{2}, 0.2 \mathrm{wt} \% \mathrm{MgO}, 55 \mathrm{wt} \% \mathrm{CaO}$, and $0.1 \mathrm{wt} \% \mathrm{Fe}_{2} \mathrm{O}_{3}$ (Table 3). The wackestone facies-particularly those found in fossiliferous limestone-indicate sedimentary deposition in a shallow marine environment. 


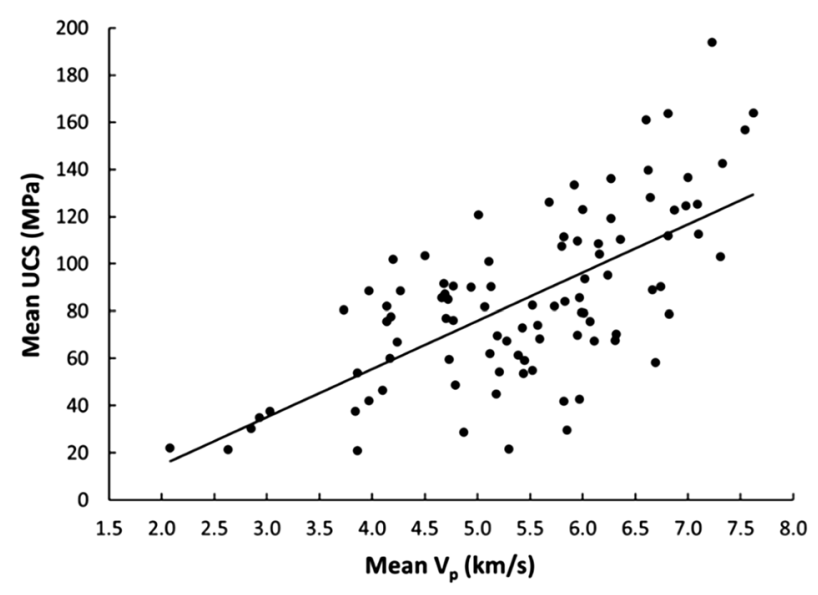

Figure 5. Relationship between the $\mathrm{V}_{\mathrm{p}}$ and UCS of limestone.

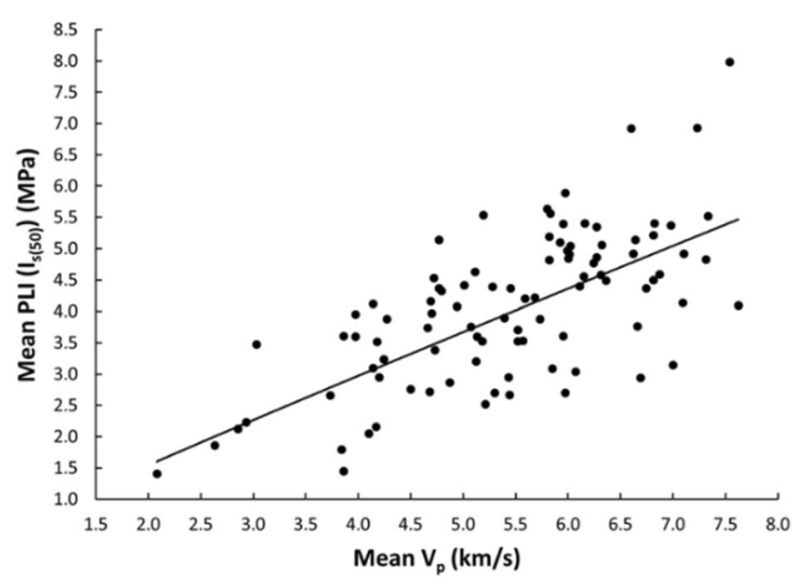

Figure 6. Relationship between the $\mathrm{V}_{\mathrm{p}}$ and PLI $\left(\mathrm{I}_{\mathrm{s}(50)}\right)$ of limestone.

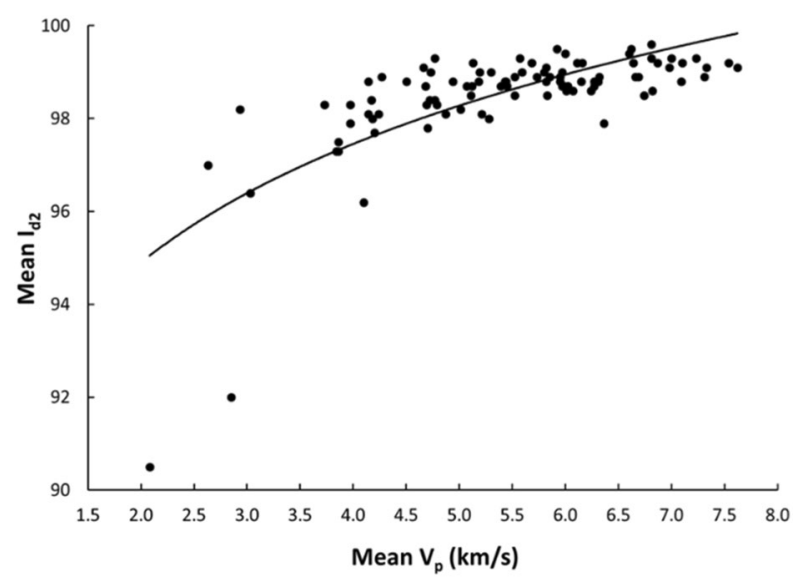

Figure 7. Relationship between the $\mathrm{V}_{\mathrm{p}}$ and $\mathrm{I}_{\mathrm{d} 2}$ of limestone.

\section{Statistical analyses and discussions}

Linear and nonlinear regression analyses are the commonly used and accepted methods for investigating empirical relationships between the mechanical and physical properties of rocks. Numerous researchers have already suggested the empirical relations between the mechanical and physical properties for specific rock types; however, studies only on carbonate/limestone were considered herein (Table 1). The rock type, composition, porosity, water 


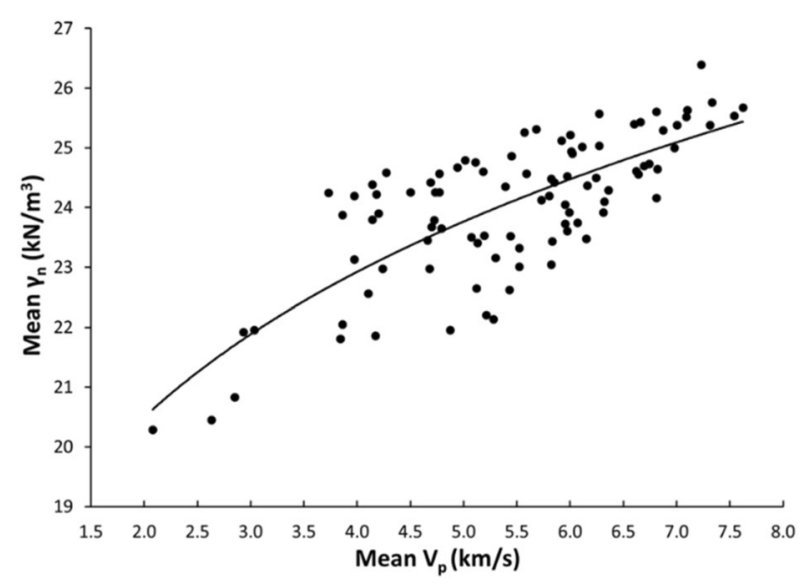

Figure 8. Relationship between the $\mathrm{V}_{\mathrm{p}}$ and $\gamma_{\mathrm{n}}$ of limestone.

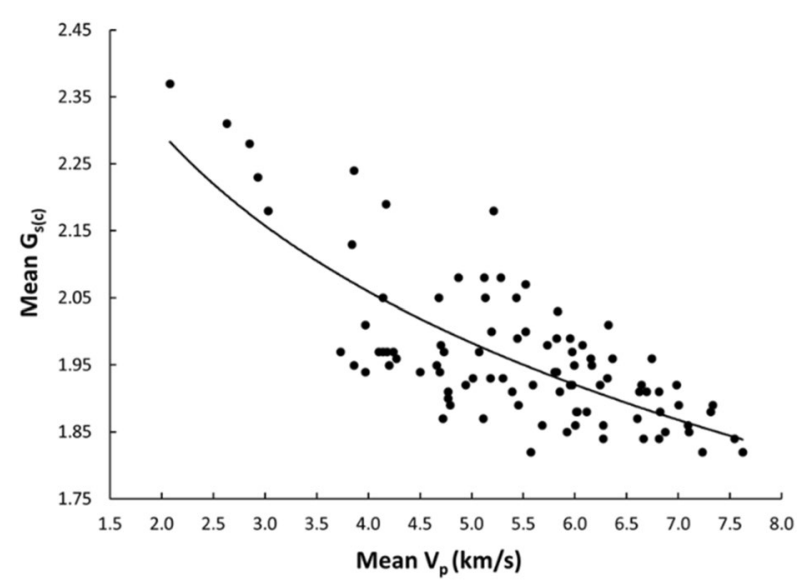

Figure 9. Relationship between the $\mathrm{V}_{\mathrm{p}}$ and $\mathrm{G}_{\mathrm{s}(\mathrm{C})}$ of limestone.

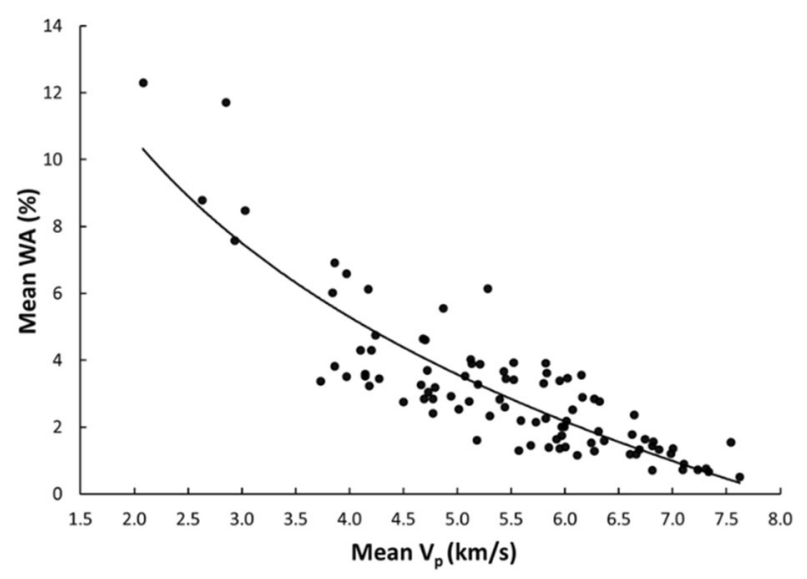

Figure 10. Relationship between the $\mathrm{V}_{\mathrm{p}}$ and WA of limestone.

content, and joints have a significant impact on the mechanical and physical properties of rocks. In this study, linear and nonlinear regression models were used to investigate the relationships between some mechanical and physical properties of limestone with respect to $V_{p}$. $95 \%$ confidences interval for the parameters were constructed. The correlation coefficient $\mathrm{R}$ which measures the strength and direction of the relationship between two variables for each regression mode was computed using the best line fit equation (Figs. 5, 6, 7, 8, 9, 10, 11). Table 4 


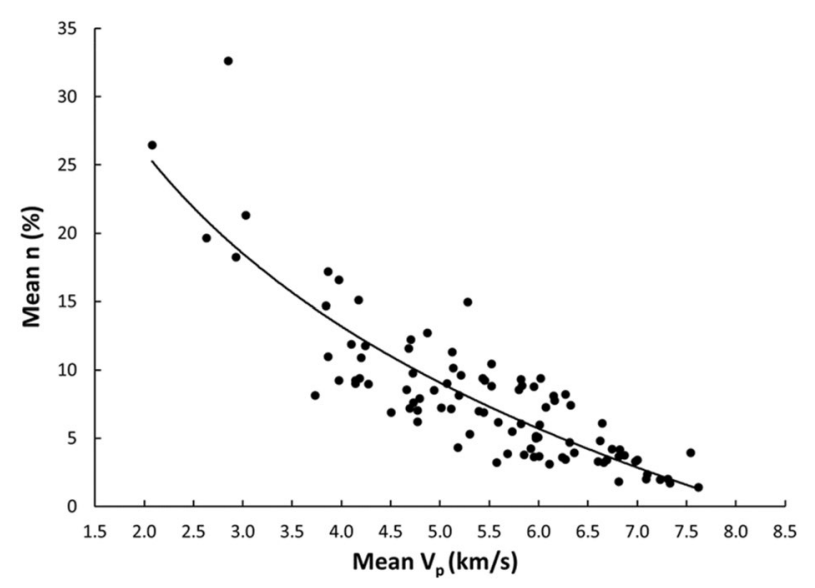

Figure 11. Relationship between the $\mathrm{V}_{\mathrm{p}}$ and $\mathrm{n}$ of limestone.

\begin{tabular}{|c|c|c|c|c|c|c|}
\hline \multirow[b]{2}{*}{ Limestone properties } & \multirow[b]{2}{*}{ Equations } & \multirow[b]{2}{*}{ R-value } & \multicolumn{4}{|c|}{$t$ tests for the parameter testing } \\
\hline & & & t-value & t-critical value & $p$-value $<\alpha=0.05$ & Confidence intervals \\
\hline \multicolumn{7}{|l|}{ Mechanical } \\
\hline UCS (MPa) & UCS $=20.395 \mathrm{~V}_{\mathrm{p}}-25.968$ & 0.67 & 8.58 & 1.662 & 0.000 & $(18.03,22.79)$ \\
\hline $\operatorname{PLI}\left(\mathrm{I}_{\mathrm{s}(50)}\right)(\mathrm{MPa})$ & $\operatorname{PLI}\left(\mathrm{I}_{\mathrm{s}(50)}\right)=0.8023 \mathrm{~V}_{\mathrm{p}}^{0.9448}$ & 0.71 & 9.54 & 1.662 & 0.000 & $(0.847,1.045)$ \\
\hline $\mathrm{I}_{\mathrm{d} 2}$ & $\mathrm{I}_{\mathrm{d} 2}=3.6869 \ln \left(\mathrm{V}_{\mathrm{p}}\right)+92.343$ & 0.72 & 10.06 & 1.662 & 0.000 & $(3.32,4.05)$ \\
\hline \multicolumn{7}{|l|}{ Physical } \\
\hline$\gamma_{\mathrm{n}}\left(\mathrm{kN} / \mathrm{m}^{3}\right)$ & $\gamma_{\mathrm{n}}=18.328 \mathrm{~V}_{\mathrm{p}}^{0.1614}$ & 0.76 & 11.37 & 1.662 & 0.000 & $(0.147,0.176)$ \\
\hline $\mathrm{G}_{\mathrm{s}(\mathrm{C})}$ & $\mathrm{G}_{\mathrm{s}(\mathrm{c})}=-0.342 \ln \left(\mathrm{V}_{\mathrm{p}}\right)+2.5333$ & -0.76 & -11.1 & 1.662 & 0.000 & $(-0.373,-0.312)$ \\
\hline WA (\%) & $\mathrm{WA}=-7.692 \ln \left(\mathrm{V}_{\mathrm{p}}\right)+15.956$ & -0.87 & -17.07 & 1.662 & 0.000 & $(-7.849,-7.247)$ \\
\hline $\mathrm{n}(\%)$ & $\mathrm{n}=-18.47 \ln \left(\mathrm{V}_{\mathrm{p}}\right)+38.8$ & -0.86 & -16.2 & 1.662 & 0.000 & $(-19.62,-17.34)$ \\
\hline
\end{tabular}

Table 4. Empirical equations between $\mathrm{V}_{\mathrm{p}}$ and some tested properties of limestone.

lists the R-values. Regression analysis revealed a strong relationship between the $V_{p}$ and the PLI, $I_{d 2}, \gamma_{n}, G_{s(c)}$, $\mathrm{WA}$, and $\mathrm{n}$ and a moderate relation between $\mathrm{V}_{\mathrm{p}}$ and UCS. Furthermore, as far as independence of the residuals is concerned, the residual plots for those models; UCS, PLI $\left(I_{s(50)}\right) I_{d 2}, \gamma_{n}, G_{s(C)}, W A, n$ and $V_{p}$ are presented in Fig. $12(\mathrm{a}-\mathrm{g}) .95 \%$ confidence intervals for the true parameters are also given in Table 4.

The validity of the models were tested using Student's $t$ test, and the confidence levels were set at $95 \%$ and $0.05(\alpha=0.05)$, respectively (Table 4$)$.

The derived equations for limestone were compared with the available equations for the same rock types in the literature (Table 1). The relationships between $V_{p}$ and UCS, PLI, $I_{d 2}, \gamma_{n}, G_{s(c)}$, WA, and $n$ obtained from this study is compared with those of obtained in previous studies (Figs. 13, 14, 15, 16, 17, 18). The R-values, which are considered a good indicator for the strength and direction of the relationship between two variables for each regression model, were computed using the best line fit equations like linear, exponential, power and logarithmic. Those models were chosen based on the empirical distribution of obtained data. As shown in Table 1 and Figs. 13, 14, 15, 16, 17 and 18, the computed equations varied and the regression coefficient (R) ranged from 0.46 to -0.98 . Such variations can be attributed to the origin and other features of rocks, including composition, porosity, and water content.

As shown in Figs. 19, 20, 21, 22, 23, 24 and 25, the predicted and measured values, which are acquired from $\mathrm{V}_{\mathrm{p}}$, were cross-correlated. The best fit between the measured and predicted values can be evaluated with the 1:1 slope line that indicates a perfect correlation; the accuracy level of the measured values declined with an increased deviation from the 1:1 slope line. This study proves the reliability of estimating the mechanical and physical properties of limestone from $\mathrm{V}_{\mathrm{p}}$ values.

\section{Conclusions}

An intensive experimental program-over 1750 tests on limestone samples collected from seven different locations along the study - were conducted using several standard testing methods. Regression analyses, both linear and nonlinear, were used to generate empirical correlations between $\mathrm{V}_{\mathrm{p}}$ and the mechanical and physical features of limestone, i.e., UCS, PLI, $\mathrm{I}_{\mathrm{d} 2}, \gamma_{\mathrm{n}}, \mathrm{G}_{\mathrm{s}(\mathrm{c})}$, WA, and $\mathrm{n}$. Based on the test results, the following conclusions were accomplished: 

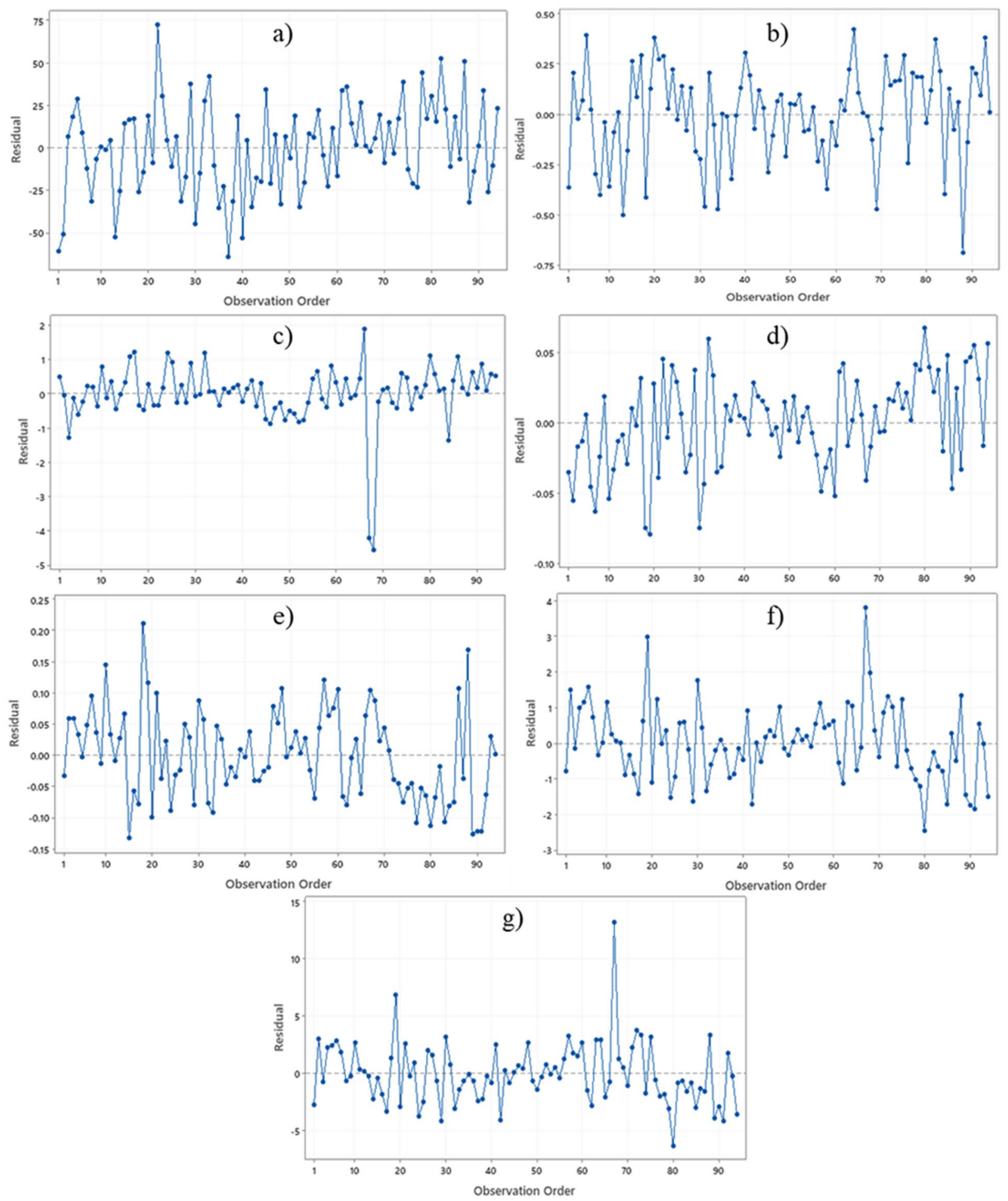

Figure 12. The residual plots of (a) UCS versus $V_{p},(\mathbf{b}) \operatorname{PLI}\left(I_{s(50)}\right)$ versus $V_{p},(\mathbf{c}) I_{d 2}$ versus $V_{p},(d) \gamma_{n}$ versus $V_{p}$, (e) $\mathrm{G}_{\mathrm{s}(\mathrm{C})}, \mathrm{V}_{\mathrm{p}},(\mathrm{f})$ WA versus $\mathrm{V}_{\mathrm{p}}$ and $(\mathrm{g}) \mathrm{n}$ versus $\mathrm{V}_{\mathrm{p}}$.

1. The statistical analyses indicate significant correlations between $V_{p}$ and UCS, PLI, $I_{d 2}, \gamma_{n}, G_{s(c)}$, WA, and $n$. Thus, a $\mathrm{V}_{\mathrm{p}}$ test-a simple, fast, economical, and nondestructive method for characterizing rock — can be used to predict the UCS, PLI, $\mathrm{I}_{\mathrm{d} 2}, \gamma_{\mathrm{n}}, \mathrm{G}_{\mathrm{s}(\mathrm{c})}$, WA, and $\mathrm{n}$ of limestone.

2. The correlation of coefficient, $R$, between UCS, PLI, $I_{d 2}$ and $V_{p}$ range $0.67-0.72$.

3. The WA, $n, \gamma_{n}$, and $G_{s(c)}$ of limestone provide the best correlation with $V_{p}(R=-0.87,-0.86,0.76$, and -0.76 , respectively). 


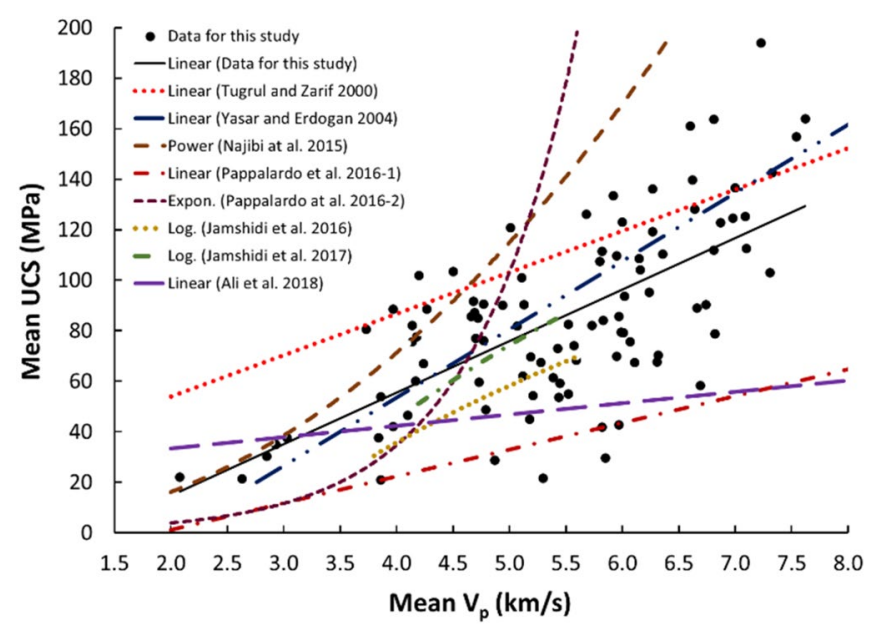

Figure 13. Comparison of results obtained in this study with those obtained in previous studies; $\mathrm{V}_{\mathrm{p}}$ versus UCS of limestone.

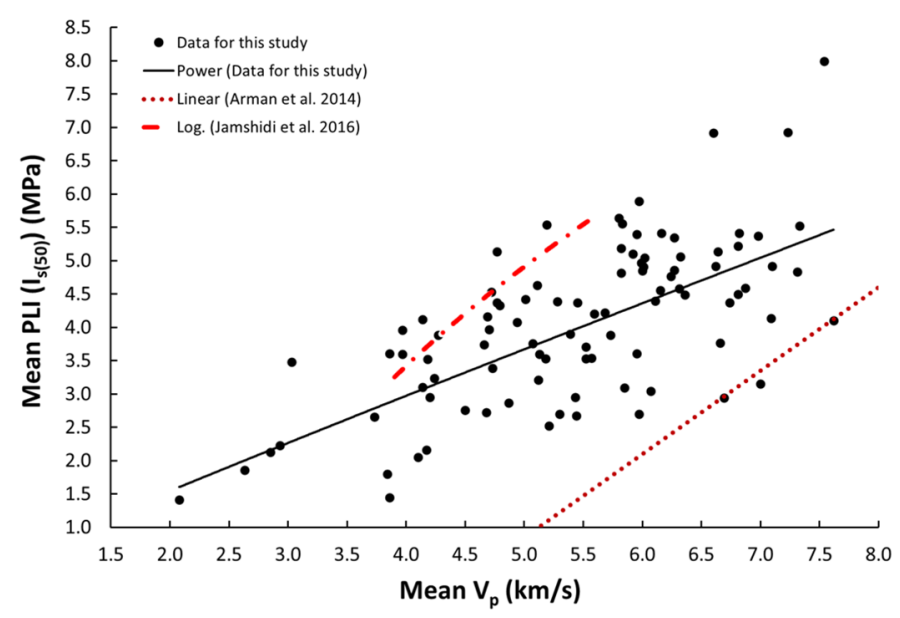

Figure 14. Comparison of results obtained in this study with those obtained in previous studies; $\mathrm{V}_{\mathrm{p}}$ versus PLI $\left(\mathrm{I}_{\mathrm{s}(50)}\right)$ of limestone.

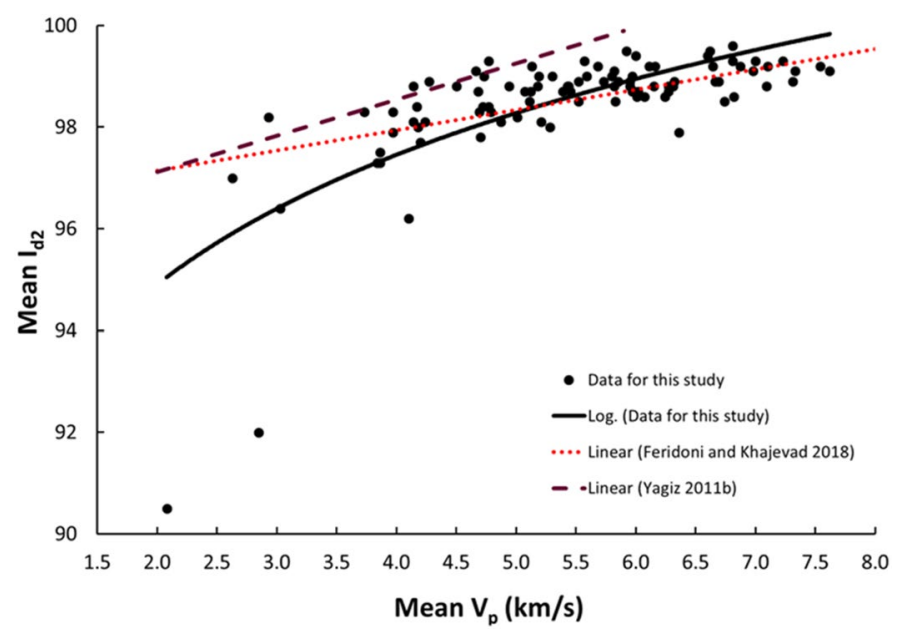

Figure 15. Comparison of results obtained in this study with those obtained in previous studies; $V_{p}$ versus $I_{d 2}$ of limestone. 


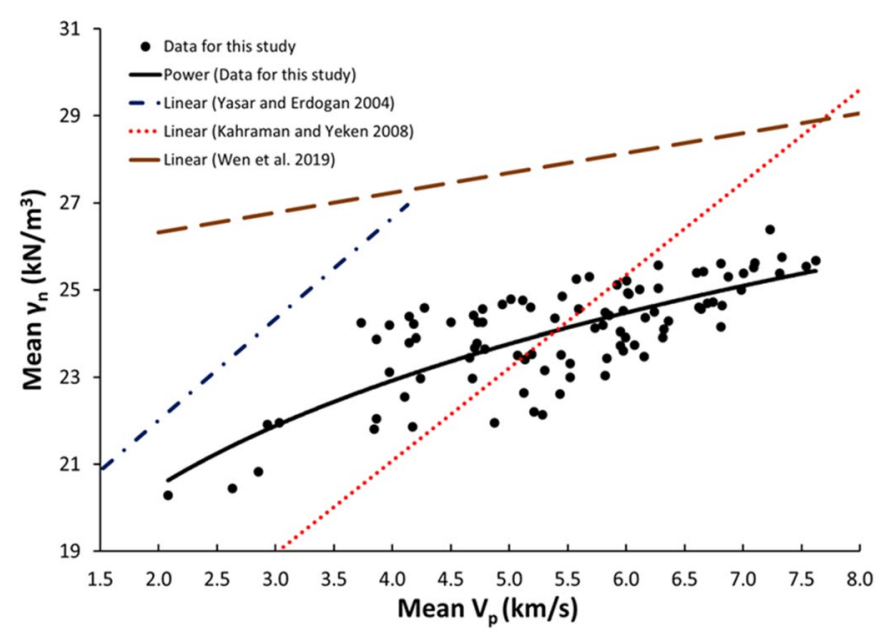

Figure 16. Comparison of results obtained in this study with those obtained in previous studies; $V_{p}$ versus $\gamma_{n}$ of limestone.

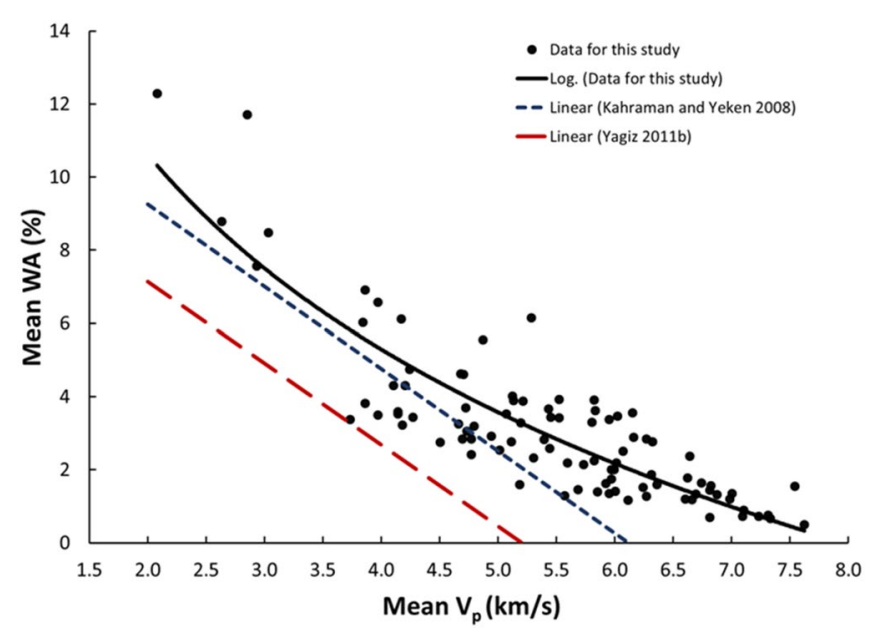

Figure 17. Comparison of results obtained in this study with those obtained in previous studies; $\mathrm{V}_{\mathrm{p}}$ versus WA of limestone.

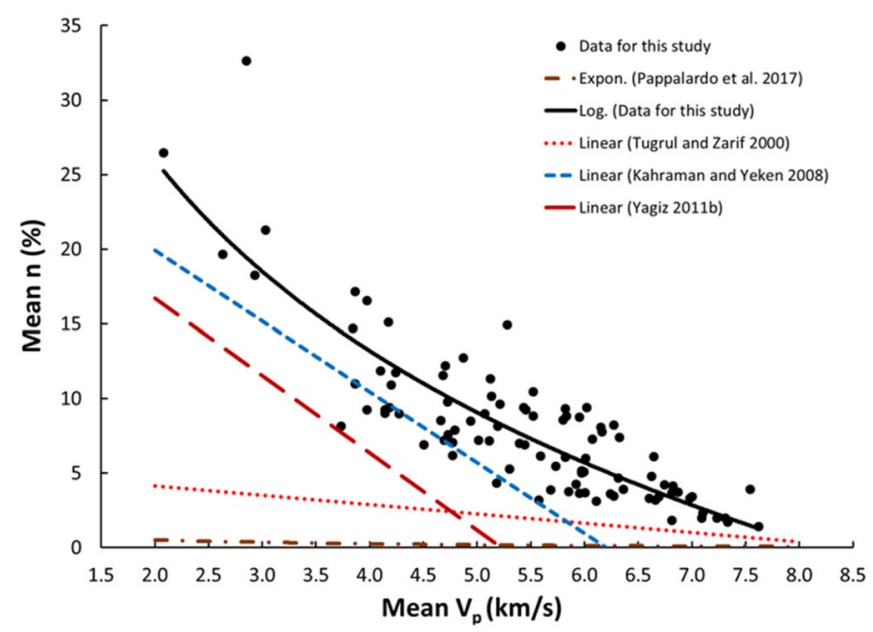

Figure 18. Comparison of results obtained in this study with those obtained in previous studies; $\mathrm{V}_{\mathrm{p}}$ versus $\mathrm{n}$ of limestone. 


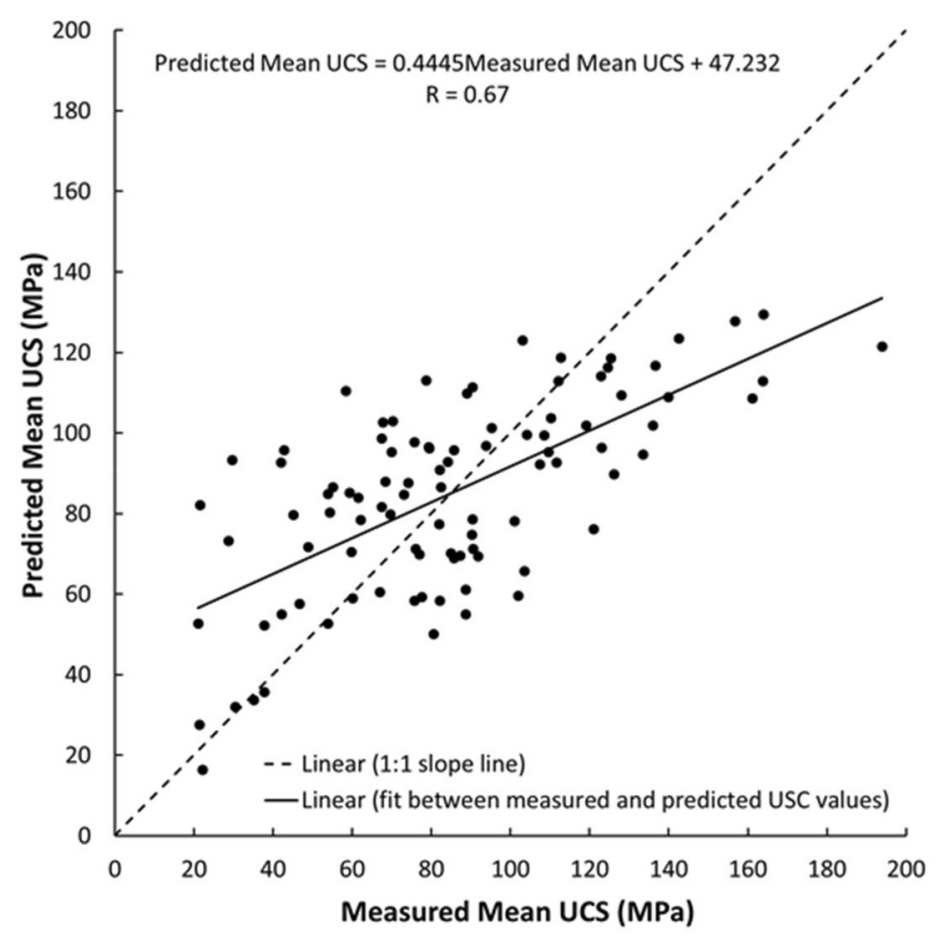

Figure 19. Cross-correlation of the measured and predicted values estimated from $V_{p}$ in terms of UCS values of limestone.

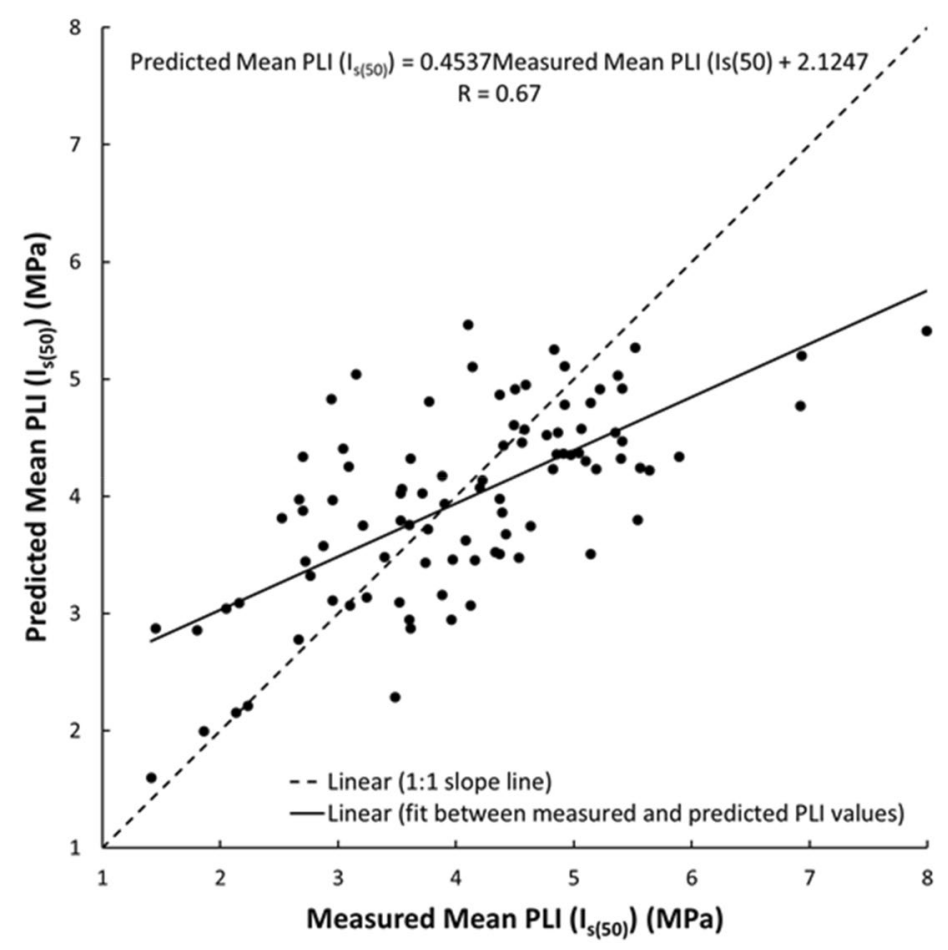

Figure 20. Cross-correlation of the measured and predicted values estimated from $\mathrm{V}_{\mathrm{p}}$ in terms of PLI $\left(\mathrm{I}_{\mathrm{s}}(50)\right)$ values of limestone. 


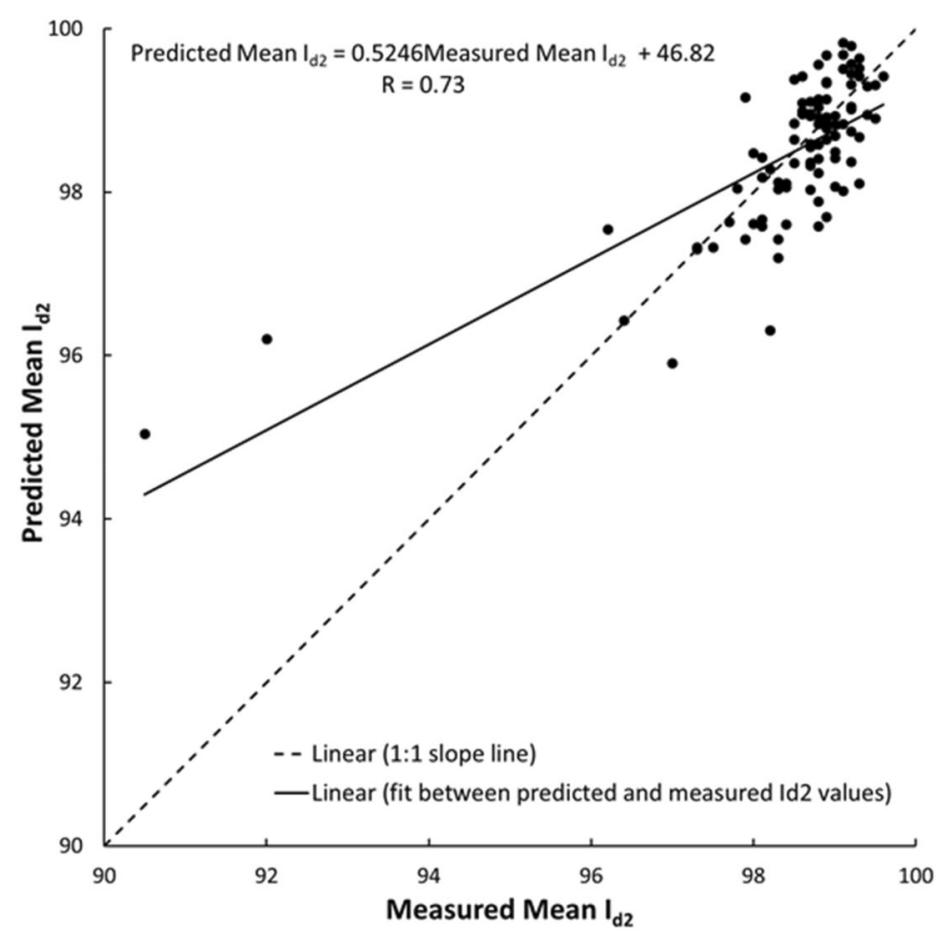

Figure 21. Cross-correlation of the measured and predicted values estimated from $V_{p}$ in terms of $I_{d 2}$ values of limestone.

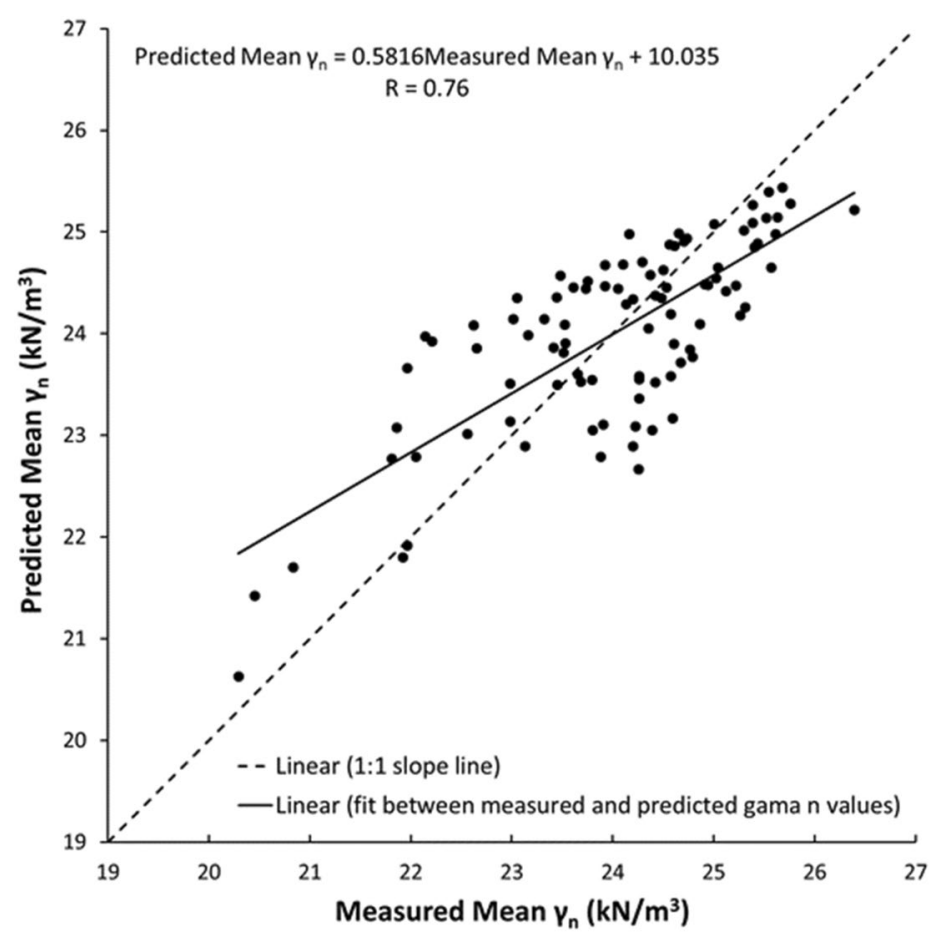

Figure 22. Cross-correlation of the measured and predicted values estimated from $V_{p}$ in terms of $\gamma_{n}$ values of limestone. 


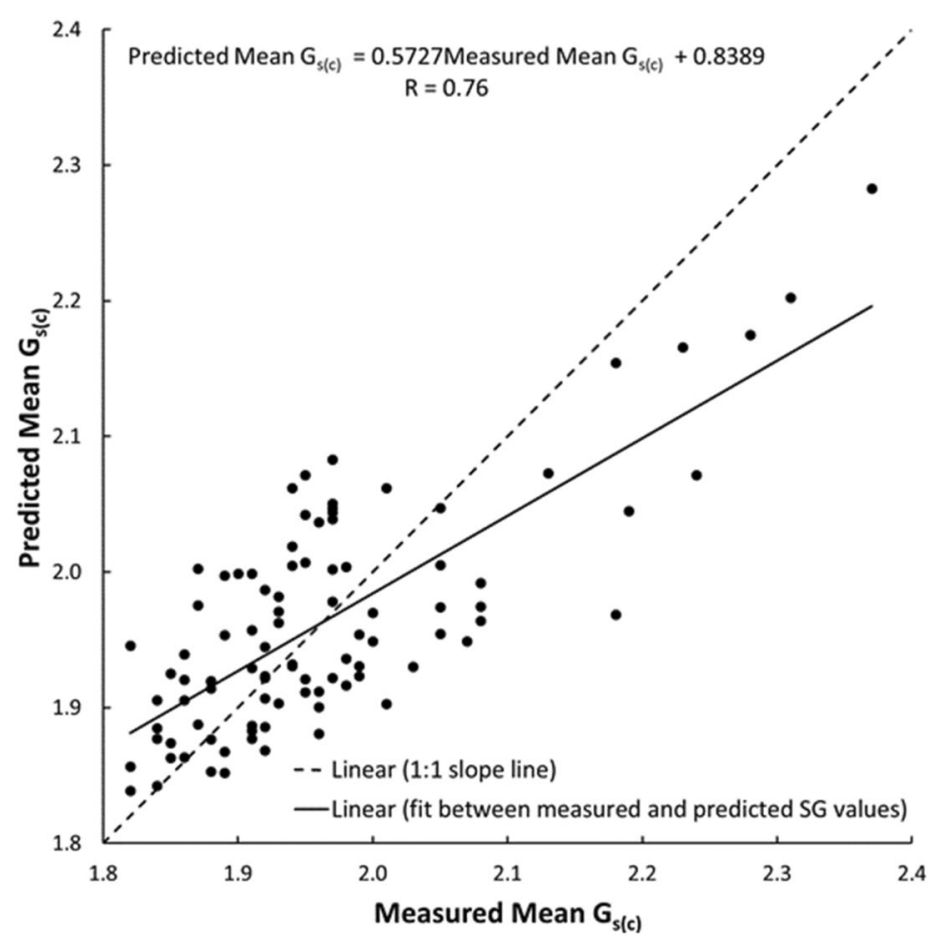

Figure 23. Cross-correlation of the measured and predicted values estimated from $V_{p}$ in terms of $G_{s(C)}$ values of limestone.

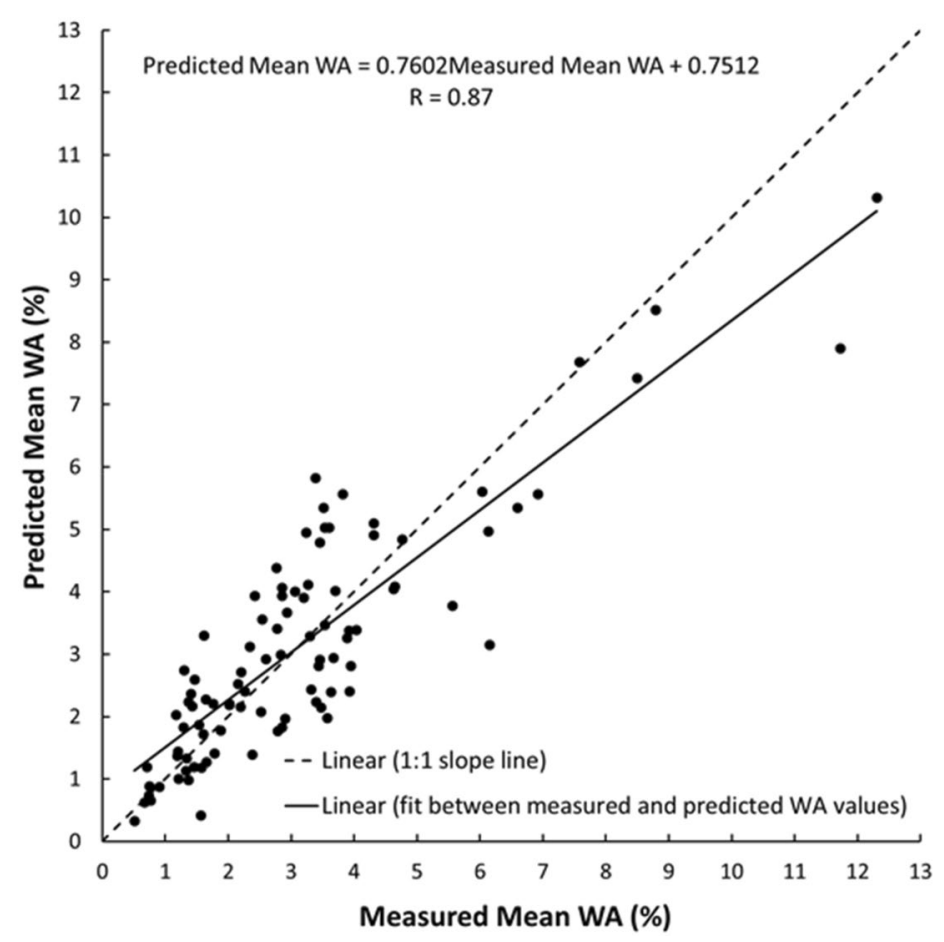

Figure 24. Cross-correlation of the measured and predicted values estimated from $V_{p}$ in terms of WA values of limestone. 


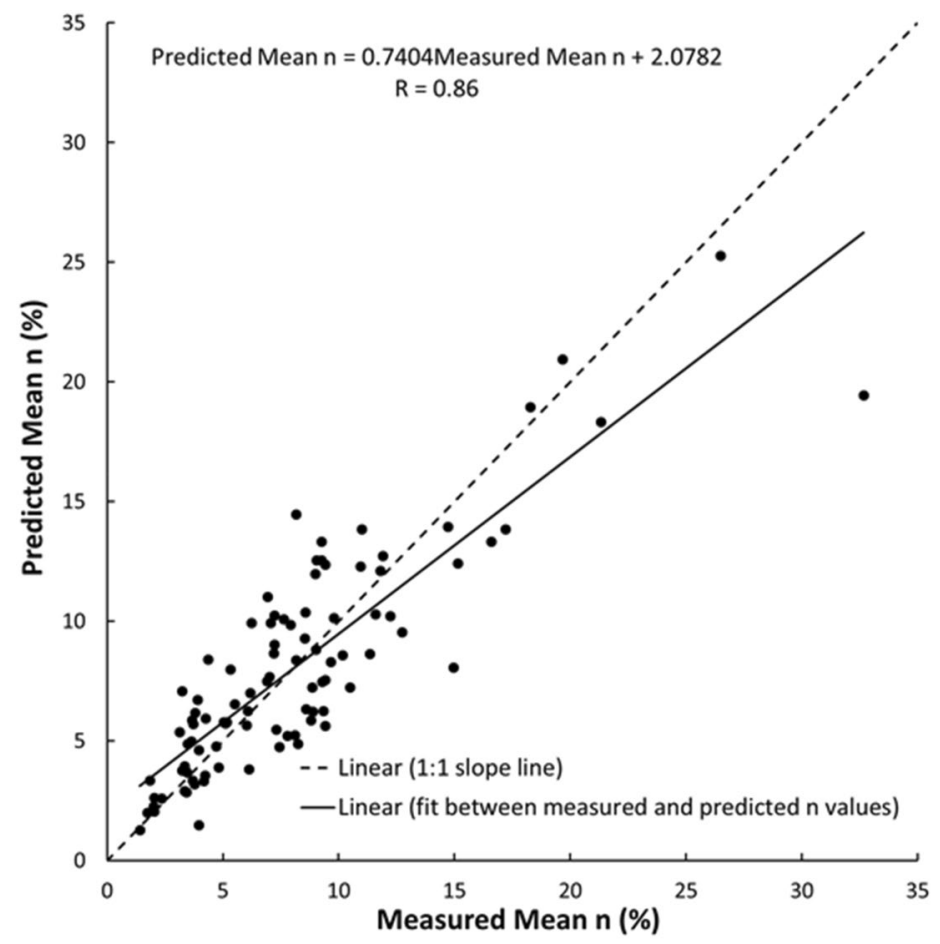

Figure 25. Cross-correlation of the measured and predicted values estimated from $V_{p}$ in terms of $n$ values of limestone.

4. For all cases, the calculated t-test statistics were highly significant which confirm the UCS, PLI, $\mathrm{I}_{\mathrm{d} 2}, \gamma_{\mathrm{n}}, \mathrm{G}_{\mathrm{s}(\mathrm{c})}$, $\mathrm{WA}$, and $\mathrm{n}$ of limestone in the study area can be reliably estimated using the proposed correlation equations.

While the results of this study may have wide common usage in engineering applications, the provided equations apply only for the specified rock. Further research is necessary to apply these results to other rock types.

Statistical analysis. Descriptive statistics of the data is presented in Table 2. Since the sample size is large $(n=94)$, the intervals within one standard deviation of the means are calculated using the empirical rule to check the data spread. The Statistical package, Minitab, is used to investigate the empirical correlations between various parameters through linear and nonlinear regression analyses. To test the validities of the regression models, the Student's $t$ tests statistics, critical values, and the p-values of the variable relationships, as well as the $95 \%$ confidence intervals of the true parameters are summarized in Table 3. According to the central limit theorem, there is no need to verify normality for large samples $(n>=30)$ since the sample mean is approximately normally distributed.

Received: 1 September 2021; Accepted: 6 December 2021

Published online: 16 December 2021

\section{References}

1. Tugrul, A. \& Zarif. I. H. Engineering aspects of limestone weathering in Istanbul, Turkey. B. Eng. Geol. Environ. 58, 191-206 (2000).

2. Yasar, E. \& Erdogan, Y. Correlating sound velocity with the density, compressive strength and Young's modulus of carbonate rocks. Int. J. Rock Mech. Min. 41, 871-875 (2004).

3. Kahraman, S. \& Yeken, T. Determination of physical properties of carbonate rocks from P-wave velocity. B. Eng. Geol. Environ. 67, 277-281 (2008).

4. Yagiz, S. Correlation between slake durability and rock properties for some carbonate rocks. B. Eng. Geol. Environ. 70, 377-383 (2011).

5. Arman, H., Hashem, W., El-Saiy, A., Abdelghany, O. \& El Tokhi, M. Petrographical and geomechanical properties of the Lower Oligocene limestones from Al Ain city, United Arab Emirates. Arab. J. Sci. Eng. 39, 261-271 (2014).

6. Wen, L., Luo, Z. Q., Yang, S. J., Qin, Y. G. \& Wang, W. Correlation of geo-mechanics parameter with uniaxial compressive strength and P-wave velocity on dolomitic limestone using a statistical method. Geotech. Geol. Eng. 37, 1079-1094 (2019).

7. Yagiz, S. P-wave velocity test for assessment of geotechnical properties of some rock materials. B. Mater. Sci. 34, 947-953 (2011).

8. Najibi, A. R., Ghafoori, M., Lashkaripour, G. R. \& Asef, M. R. Empirical relations between strength and static and dynamic elastic properties of Asmari and Sarvak limestones, two mail oil reservoirs in Iran. J. Petrol. Sci. Eng. 126, 78-82 (2015).

9. Stan-Kieczek, I. The study of the elastic properties of carbonate rocks on a base of laboratory and field measurements. Acta Montan. Slovaca. 21, 76-83 (2016).

10. Pappalardo, G., Mineo, M. \& Monaco, C. Geotechnical characterization of limestones employed for the reconstruction of a UNESCO world heritage Baroque monument in southeastern Sicily (Italy). Eng. Geol. 212, 86-97 (2016). 
11. Jamshidi, A., Nikudel, M. R., Khamechchiyan, M., Sahamich, R. Z. \& Abdi, Y. A correlation between P-wave velocity and Schmidt hardness. Arab. J. Geosci. 9, 568 (2016).

12. Jamshidi, A., Zamanian, H. \& Sahamieh, R. Z. The effect of density and porosity on the correlation between uniaxial compressive strength and P-wave velocity. Int. J. Rock Mech. Min. 51, 1279-1286 (2017).

13. Fereidooni, D. \& Khajevand, R. Correlations between slake-durability index and engineering properties of some travertine samples under wetting-drying cycles. Geotech. Geol. Eng. 36, 1071-1089 (2018).

14. Ali, S. \& Haider, R. A comparative evaluation on indirect methods to estimate the compressive strength of limestone (Chorgali Formation). In: Hoyos L., McCartney J. (eds) Advances in Characterization and Analysis of Expansive Soils and Rocks. GeoMEast 2017. Sustainable Civil Infrastructures (Springer, Cham, 2018), pp. 189-201.

15. Kurtulus, C., Sertcelik, F. \& Sertcelik, I. Estimation of unconfined compressive strength using Schmidt hardness and ultrasonic pulse velocity. Tehnicki Vjesnik. 25, 1569-1574 (2018).

16. Hunting Geology and Geophysics Limited Report on a mineral survey of the U.A.E., Al Ain area. Ministry of Petroleum and Mineral Resources, Abu Dhabi, pp. 1-129 (1979).

17. Warrak, M. Origin of the Hafit structure: implication for timing the Tertiary deformation in the northern Oman Mountain. J. Struct. Geol. 18, 803-818 (1996).

18. Noweir, M. A. Back-trust origin of the Hafit structure, Northern Oman Mountain front, United Arab Emirates. GeoArabia 5, 215-228 (2000).

19. Styles, M. T. et al. The Geology and geophysics of the United Arab Emirates. Geology, volume 2 (Keyworth, Nottingham: British Geological Survey) (2006).

20. Geological Map of Abu Dhabi Digital Map, 1:100 000, United Arab Emirates. United Arab Emirates Ministry of Energy, Department of Geology and Mineral Resources (2006).

21. Environmental Systems Research Institute (ESRI), ArcGIS Desktop: Release 10.8, Redlands, CA (2020).

22. Arman, H., Abdelghany, O., Hashem, W. \& Aldahan, A. Effects of lithofacies and environment on in situ and laboratory Schmidt hammer tests: A case study of carbonate rocks. Q. J. Eng. Geol. Hydroge. 50, 179-186 (2017).

23. Faris, M., Abdelghany, O. \& Abu Saima, M. Upper Cretaceous to Lower Eocene calcareous nannofossil biostratigraphy from Malaqet and Mundassah sections western flank of the Northern Oman Mountains. Geol. Croat. 65, 393-410 (2012).

24. Abdelghany, O., Arman, H., Gabr, A., Abu Saima, M., Fowler, A. and Aldahan, A. Geological characterization of Barzaman Formation using electrical resistivity method, Northwest of Al Ain City, UAE. In Fifth International Conference on Engineering Geophysics (ICEG), pp. 159-162 (2020).

25. ASTM D2845-08. Standard test method for laboratory determination of pulse velocities and ultrasonic elastic constants of rock (Withdrawn 2017), ASTM International, West Conshohocken, PA (2008).

26. ASTM D4543-08el. Standard practices for preparing rock core as cylindrical test specimens and verifying conformance to dimensional and shape tolerances (Withdrawn 2017), ASTM International, West Conshohocken, PA (2008).

27. Anon, O. H. Classification of rocks and soils for engineering geological mapping. Part 1-Rock and soil materials. Bull. Int. Assoc. Geol. 19, 364-371 (1979).

28. ASTM D2938-95. Standard test method for unconfined compressive strength of intact rock core specimens, ASTM International, West Conshohocken, PA (1995).

29. ASTM D4644-16. Standard test method for slake durability of shales and other similar weak rocks, ASTM International, West Conshohocken, PA (2016).

30. ASTM D5731-16. Standard test method for determination of the point load strength index of rock and application to rock strength classifications, ASTM International, West Conshohocken, PA (2016).

31. Franklin, J. A. \& Chandra, R. The slake-durability test. Int. J. Rock Mech. Min. 9, 325-328 (1972).

32. ISRM Suggested Methods. Rock characterization testing and monitoring. In: Brown, E.T. (ed.) International Society of Rock Mechanics. Commission on Testing Methods. Pergamon Press, Oxford, England (1981).

\section{Acknowledgements}

The United Arab Emirates University, Research Affairs, funds this research under the title of UPAR 2016-31S252 program. The author wishes to express special thanks to his colleagues, Dr. Osman Abdelghany, Dr. Mahmoud Abu Saima, and Dr. Baha Mahmood Amin for thin sections, SEM, XRD, and XRF analyses, research assistant, technicians and the graduate and under graduate students who took part at different levels of the field and laboratory work and interpretations. Further, author also thanks to Dr. Mohamed Yusuf Hassan for his valuable suggestions and comments on the statistical analyses.

\section{Author contributions}

1 : This is a single paper.

\section{Competing interests}

The author declares no competing interests.

\section{Additional information}

Correspondence and requests for materials should be addressed to H.A.

Reprints and permissions information is available at www.nature.com/reprints.

Publisher's note Springer Nature remains neutral with regard to jurisdictional claims in published maps and institutional affiliations. 
(c) (i) Open Access This article is licensed under a Creative Commons Attribution 4.0 International cc) License, which permits use, sharing, adaptation, distribution and reproduction in any medium or format, as long as you give appropriate credit to the original author(s) and the source, provide a link to the Creative Commons licence, and indicate if changes were made. The images or other third party material in this article are included in the article's Creative Commons licence, unless indicated otherwise in a credit line to the material. If material is not included in the article's Creative Commons licence and your intended use is not permitted by statutory regulation or exceeds the permitted use, you will need to obtain permission directly from the copyright holder. To view a copy of this licence, visit http://creativecommons.org/licenses/by/4.0/.

(C) The Author(s) 2021 